IRA-International Journal of Management \& Social Sciences

ISSN 2455-2267; Vol.06, Issue 03 (2017)

Pg. no. 486-494

Institute of Research Advances

https://research-advances.org/index.php/RAJMSS

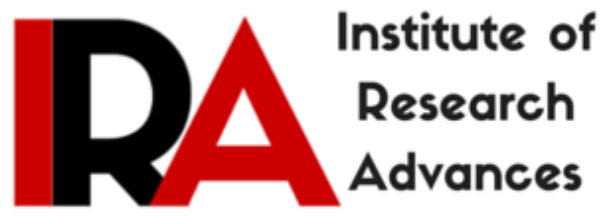

\title{
Measurement of Technical Efficiency of Durian Production in Thailand: An Application of Data Envelopment Analysis Approach
}

\author{
Surakiat Parichatnon ${ }^{1}$, Kamonthip Maichum ${ }^{2}$ and Ke-Chung Peng ${ }^{3}$ \\ 1,2 Department of Tropical Agriculture and International Cooperation, National Pingtung \\ University of Science and Technology, No.1, Shuefu Road, Neipu, Pingtung 91201, Taiwan. \\ ${ }^{3}$ Department of Agribusiness Management, National Pingtung University of Science and \\ Technology, No. 1, Shuefu Road, Neipu, Pingtung, 91201, Taiwan.
}

Type of Review: Peer Reviewed.

DOI: http://dx.doi.org/10.21013/jmss.v6.n3.p13

\section{How to cite this paper:}

Parichatnon, S., Maichum, K., \& Peng, K. (2017). Measurement of Technical Efficiency of Durian Production in Thailand: An Application of Data Envelopment Analysis Approach. IRA-International Journal of Management \& Social Sciences (ISSN 2455-2267), 6(3), 486494. doi:http://dx.doi.org/10.21013/jmss.v6.n3.p13

(C) Institute of Research Advances

\section{(cc) EY-NO}

This work is licensed under a Creative Commons Attribution-Non Commercial 4.0 International License subject to proper citation to the publication source of the work.

Disclaimer: The scholarly papers as reviewed and published by the Institute of Research Advances (IRA) are the views and opinions of their respective authors and are not the views or opinions of the IRA. The IRA disclaims of any harm or loss caused due to the published content to any party. 
IRA-International Journal of Management \& Social Sciences

\begin{abstract}
The purpose of this paper is to investigate and measure the technical efficiency of durian production in each province of Thailand using the data envelopment analysis (DEA) during the period 2012-2016. The findings indicate that the technical efficiency of Thai durian production revealed favorable results from 2012 to 2016 but still needs to be improved since the technical efficiency score is not close to 1.000. On the other hand, Chanthaburi province had the highest mean efficiency score and was recognized as the best province for Thai durian production. Moreover, the study found that Phuket province had lowest mean technical efficiency score of Thai durian production, which therefore should be increased the quantity of the outputs and inputs. Therefore, the results of this study can provide important information to farmers, agricultural planners and government agencies to help increase the technical efficiency levels of durian production in Thailand.
\end{abstract}

Keywords: Data envelopment analysis; Durian production; Technical efficiency; Thailand

\title{
Introduction
}

Durian is well known in Southeast Asia as being "King of Fruits". According to the Office of Agricultural Economics (OAE), Thailand is the largest durian producer in the world and durian production in 2016 was 656,777 tons. Moreover, Thailand is the leading exporter of durian in the world, and the major export markets are Taiwan, Hong Kong, Malaysia, China and United States. According to National Statistical Office of Thailand, the planted area is more than 0.1 million hectares and the total harvested area has increased continuously. Major production areas of durian are eastern region and southern region of Thailand. Durian production involved 0.3 million families of farmers, which accounts for more than 1 million people across the country and includes entrepreneurs, laborers, and government officials (OAE, 2016). In addition, durian production plays an important role in Thailand's economy and society. In the past, numerous studies have examined the economic efficiency and aggregate levels of Thai agriculture (Krasachat, 2004). However, a very few studies have focused on the technical efficiency (TE) of Thai durian production in each province. Durian production in each area of Thailand is different and unstable ground, resulting in different production efficiency. Therefore, this study aims to investigate and measure the TE of durian production in each province of Thailand from 2012 to 2016 by using data envelopment analysis (DEA) model.

DEA is a non-parametric method to measure the TE and productivity of decision-making units (DMUs) according to multiple inputs and outputs (Hadad, Friedman, Sinuany-Stern, \& Ben-Yair, 2008; Sexton, 1986). Previous studies have reported that the basic factors of production, such as, land, labor and capital have been considered as assessment parameters of sustainable development (Longpichai, Perret, \& Shivakoti, 2012; Parichatnon, Maichum, \& Peng, 2017; Van Passel, Van Huylenbroeck, Lauwers, \& Mathijs, 2009). Wijnhoud, Konboon, and Lefroy (2003) found that the inputs and outputs variables are important socio-economic factors and impact on the long-term sustainability. Thus, the measurement of efficiency score depends on inputs and outputs variables, which is consistent with numerous studies. In addition, previous research has suggested that performance measures are derived from the difference in the labor force, fertilizers, pesticides and machinery to produce durian fruits in different areas (Parichatnon et al., 2017; Rahman \& Rahman, 2009; Sherlund, Barrett, \& Adesina, 2002). Krasachat (2012) measured the efficiency of organic durian farms in Thailand and had one output (quantity of durian) and three inputs (land, human labor and total costs). Son, Coelli, and Fleming (1993) applied DEA model for analysis of the agricultural performance in Vietnam. Mohammadi et al. (2015) used DEA to measure the TE of agricultural farm and had one output variable (quantity of farm produce) and had eight input variables (fertilizer, chemicals, seed, labor, machinery, diesel, electricity and water). Furthermore, Krasachat (2014) studied the effects of socio-economic factors of farms and farm management factors by using DEA approach and Tobit regression model. The results found that durian 
quantity, land, labor force and other inputs have a major influence on efficiency performance of durian farm.

\section{Research Methodology}

\section{DEA model}

DEA is the most widely used technique in agricultural economics (Meeusen \& Van den Broeck, 1977). DEA was developed by Charnes, Cooper, and Rhodes (1978) and was based on constant returns to scale (CRS) and was subsequently expanded by Banker, Charnes, and Cooper (1984) to accommodate technologies that exhibit variable returns to scale (VRS). According to Coelli, Prasada Rao, O'Donnell, and Battese (2005), the advantage of using this technique is that it can evaluate the performance of individual DMUs. In this study, we used CCR (Charnes Cooper and Rhodes) model developed by Charnes et al. (1978), which, based on CRS model. Moreover, we also used the DMU to refer to any entity that has been evaluated for its ability to convert inputs into results. This study selected $\mathrm{n}(\mathrm{n}=$ DMUs $=22$ provinces) to evaluate the TE of Thai durian production. Thus, to evaluate each DMU we propose to use the equation as follows (Charnes et al., 1978):

$$
T E_{q}=\frac{\sum_{r=1}^{t} u_{r} y_{r q}}{\sum_{i=1}^{m} v_{i} x_{i q}}
$$

Here, $T E_{q}$ is technical efficiency of firm $q$ using $m$ inputs to produce $t$ outputs; $y_{r q}$ is the quantity of output $r$ produced by firm $q ; x_{i q}$ is the quantity of input $i$ consumed by firm $q ; u_{r}$ is the weight of output $r ; v_{i}$ is the weight of input $i$. All data are run through the linear program with the input and output matric. The TE scores are ranked from 0 to 1.000 .

\section{Data and Variables}

We analyzed durian production in Thailand from 2012 to 2016. Therefore, the study used the secondary data collected from surveys by various Thai governmental agencies: Office of Agricultural Economics, Department of Internal Trade and Ministry of Labor. The research area covered 22 provinces across four regions in Thailand, namely Chanthaburi, Chumphon, Krabi, Nakhonnayok, Nakhonphanom, Nakornsrithammarat, Narathiwat, Nonthaburi, Pattani, Phangnga, Phatthalung, Phuket, Prachinburi, Ranong, Rayong, Satun, Songkhla, Suratthani, Trang, Trat, Uttaradit and Yala. This study analyzed a total of six inputs, namely planted area (X1), harvested area (X2), human labor (X3), machinery (X4), fertilizer (X5) and pesticide (X6), and one output, namely quantity of durian (Y). Data descriptions can be seen in Table 1. Data analyses were conducted using data envelopment analysis program (DEAP 2.1) and statistical package for social sciences (SPSS 23.0). Descriptive statistics of the variable items are presented in Table 2. The results showed that on average, planted area was 107,762.08 ha, while the harvested area was 94,854.40 ha, human labor had a very high number at 1,428.93 hr/ha, machinery was $32.55 \mathrm{hr} / \mathrm{ha}$, fertilizer was high at $18,357.73$ tons and also pesticide was 2,130.42 tons in durian production sector. Furthermore, the average of durian quantity was 552,912.30 tons. 
Table 1. Data descriptions of variables items and resource

\begin{tabular}{|c|c|c|c|}
\hline Variables & Unit & Definition & Source \\
\hline \multicolumn{4}{|l|}{ Inputs } \\
\hline Planted area & hectare (ha) & $\begin{array}{l}\text { Agricultural land that is } \\
\text { used for durian growing. }\end{array}$ & $\begin{array}{l}\text { Mohammadi et al. } \\
\text { (2015)and Krasachat (2014) }\end{array}$ \\
\hline Harvested area & hectare (ha) & $\begin{array}{l}\text { Total area for durian } \\
\text { production. }\end{array}$ & $\begin{array}{l}\text { Tung (2014) and Krasachat } \\
\text { (2012) }\end{array}$ \\
\hline Human labor & $\begin{array}{l}\text { hour per ha } \\
\text { (hr/ha) }\end{array}$ & $\begin{array}{l}\text { The workers who are } 15- \\
60 \text { years old and engaged } \\
\text { in durian production. }\end{array}$ & $\begin{array}{l}\text { Krasachat (2014) and } \\
\text { Rahman, Wiboonpongse, } \\
\text { Sriboonchitta, and } \\
\text { Chaovanapoonphol (2009) }\end{array}$ \\
\hline Machinery & $\begin{array}{l}\text { hour per hectare } \\
\text { (hr/ha) }\end{array}$ & $\begin{array}{l}\text { The total power of farm } \\
\text { machinery. }\end{array}$ & $\begin{array}{l}\text { Nassiri and Singh (2009) } \\
\text { and Rahman and Rahman } \\
(2009)\end{array}$ \\
\hline Fertilizer & tons & $\begin{array}{l}\text { Total number of the } \\
\text { chemical fertilizers used in } \\
\text { durian-farming } \\
\text { production. }\end{array}$ & $\begin{array}{l}\text { Mailena, Shamsudin, } \\
\text { Radam, and Latief (2014), } \\
\text { Nassiri and Singh (2009) } \\
\text { and Dhungana, Nuthall, and } \\
\text { Nartea (2004) }\end{array}$ \\
\hline Pesticide & tons & $\begin{array}{l}\text { Total number of } \\
\text { substances that are intently } \\
\text { used for destroying, } \\
\text { mitigating and preventing } \\
\text { any pest. Pesticides } \\
\text { included insecticides, } \\
\text { herbicides, fungicide and } \\
\text { bactericides. }\end{array}$ & $\begin{array}{l}\text { Mailena et al. (2014) and } \\
\text { Tung (2014) }\end{array}$ \\
\hline \multicolumn{4}{|l|}{ Output } \\
\hline $\begin{array}{l}\text { Quantity } \\
\text { durian }\end{array}$ & tons & $\begin{array}{l}\text { Total durian quantity of all } \\
\text { the production. }\end{array}$ & $\begin{array}{l}\text { Krasachat } \\
\text { Krasachat (2012) }\end{array}$ \\
\hline
\end{tabular}

Table 2. Descriptive statistics of the variable items

\begin{tabular}{|c|c|c|c|c|c|}
\hline Variables & Unit & Average & $\begin{array}{l}\text { Standard } \\
\text { deviation }\end{array}$ & Maximum & Minimum \\
\hline \multicolumn{6}{|l|}{ Inputs } \\
\hline Planted area & hectare (ha) & $107,762.08$ & $98,802.40$ & $208,389.30$ & $5,290.38$ \\
\hline Harvested area & hectare (ha) & $94,854.40$ & $91,470.65$ & $130,842.59$ & $3,365.90$ \\
\hline Human labor & $\begin{array}{l}\text { hour per ha } \\
\text { (hr/ha) }\end{array}$ & $1,428.93$ & $1,093.32$ & $3,491.60$ & 340.52 \\
\hline
\end{tabular}


IRA-International Journal of Management \& Social Sciences

\begin{tabular}{llllll}
\hline Machinery & $\begin{array}{l}\text { hour per hectare } \\
\text { (hr/ha) }\end{array}$ & 32.55 & 13.09 & 54.85 & 12.31 \\
Fertilizer & tons & $18,357.73$ & $14,658.03$ & $43,930.35$ & $2,540.12$ \\
Pesticide & tons & $2,130.42$ & $1,185.22$ & $4,320.15$ & 643.00 \\
\hline Output & & & & & \\
\hline Quantity of durian & tons & $752,912.30$ & $602,450.12$ & $653,921.31$ & 58.39 \\
\hline
\end{tabular}

\section{Results and Discussion}

The efficiency measure was assessed through DEAP 2.1 software to analyze TE level of Thai durian production in 22 provinces. Consequently, Table 3 shows that the efficiency scores of Thai durian production. The results found that the average TE score of durian production from 2012 to 2016 was 0.652 , standard deviation was 0.177 , average maximum of TE score was 0.978 and average minimum of TE score was 0.362 , respectively. It can be seen that average TE scores are relatively moderate, thus, it is necessary to improve the operational efficiency of durian production in Thailand.

Regarding TE in each year, we found that the average TE score in 2012 was 0.637 ; it also found that the Chanthaburi province had the highest efficiency $(0.957)$ and Nakhonnayok province had the lowest efficiency (0.339). In 2013, the results shows that the average TE score was 0.642, and Chanthaburi province had a high efficiency score (0.970) and Phuket province had a low efficiency score $(0.362)$. Durian production in 2014 had an average TE score of 0.648; Chanthaburi province revealed the highest average score at 1.000 and Phuket province performed the lowest average score of 0.340 . The average TE score of Thai durian production in 2015 was 0.664 ; Rayong province had very high scores at 1.000 and Nonthaburi province had the lowest score at 0.378 . Moreover, the average efficiency score of all data in 2016 was 0.669 ; Chanthaburi province had a good efficient performance (0.962) and Nonthaburi province had the worst efficiency TE score (0.391). Therefore, it is summary that Thai durian production in 2016 had a better average TE score than the other years.

Furthermore, Figure 1 shows that the TE score of durian production in each DMU. Chanthaburi province had the most efficient durian production from year 2012 to 2016, followed by Rayong province, Trat province, Chumphon province, Suratthani province, Uttaradit province, Nakornsrithammarat province, Phatthalung province, Yala province, Phangnga province, Satun province, Pattani province, Narathiwat province, Ranong province, Krabi province, Trang province, Songkhla province, Prachinburi province, Nakhonphanom province, Nonthaburi province, Nakhonnayok province and Phuket province. The findings from this study suggests that it could be improved the production to increase the efficiency performance of durian production in Thailand.

Table 3. Efficiency scores of the durian production

\begin{tabular}{lllllll}
\hline DMUs & 2012 & 2013 & 2014 & 2015 & 2016 & Average \\
\hline Chanthaburi & 0.957 & 0.970 & 1.000 & 0.933 & 0.962 & 0.964 \\
Chumphon & 0.903 & 0.883 & 0.863 & 0.845 & 0.891 & 0.877 \\
Krabi & 0.604 & 0.572 & 0.564 & 0.588 & 0.597 & 0.585 \\
Nakhonnayok & 0.339 & 0.376 & 0.397 & 0.411 & 0.418 & 0.388 \\
Nakhonphanom & 0.442 & 0.419 & 0.398 & 0.424 & 0.437 & 0.424 \\
Nakornsrithammarat & 0.708 & 0.729 & 0.723 & 0.737 & 0.742 & 0.728 \\
\hline
\end{tabular}


IRA-International Journal of Management \& Social Sciences

\begin{tabular}{lllllll}
\hline Narathiwat & 0.611 & 0.589 & 0.604 & 0.612 & 0.623 & 0.608 \\
Nonthaburi & 0.421 & 0.398 & 0.407 & 0.378 & 0.391 & 0.399 \\
Pattani & 0.629 & 0.637 & 0.652 & 0.694 & 0.706 & 0.664 \\
Phangnga & 0.647 & 0.690 & 0.713 & 0.708 & 0.693 & 0.690 \\
Phatthalung & 0.726 & 0.698 & 0.667 & 0.684 & 0.704 & 0.696 \\
Phuket & 0.378 & 0.362 & 0.340 & 0.392 & 0.416 & 0.378 \\
Prachinburi & 0.479 & 0.480 & 0.511 & 0.527 & 0.516 & 0.503 \\
Ranong & 0.539 & 0.567 & 0.575 & 0.589 & 0.574 & 0.569 \\
Rayong & 0.867 & 0.890 & 0.902 & 1.000 & 0.889 & 0.910 \\
Satun & 0.638 & 0.643 & 0.678 & 0.690 & 0.707 & 0.671 \\
Songkhla & 0.503 & 0.529 & 0.548 & 0.587 & 0.564 & 0.546 \\
Suratthani & 0.811 & 0.799 & 0.771 & 0.874 & 0.886 & 0.828 \\
Trang & 0.512 & 0.529 & 0.567 & 0.550 & 0.581 & 0.548 \\
Trat & 0.832 & 0.868 & 0.890 & 0.901 & 0.922 & 0.883 \\
Uttaradit & 0.754 & 0.789 & 0.805 & 0.810 & 0.814 & 0.794 \\
Yala & 0.710 & 0.704 & 0.673 & 0.683 & 0.690 & 0.692 \\
\hline Average & 0.637 & 0.642 & 0.648 & 0.664 & 0.669 & 0.652 \\
Standard deviation & 0.174 & 0.178 & 0.179 & 0.180 & 0.175 & 0.177 \\
Maximum & 0.957 & 0.970 & 1.000 & 1.000 & 0.962 & 0.978 \\
Minimum & 0.339 & 0.362 & 0.340 & 0.378 & 0.391 & 0.362 \\
\hline
\end{tabular}




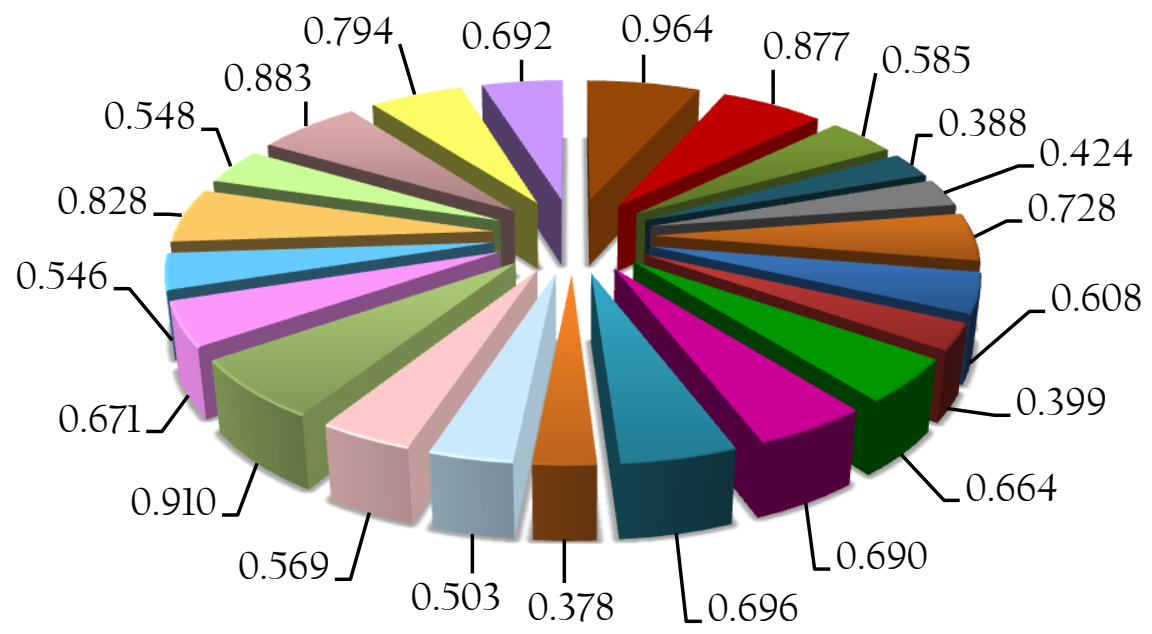

$\begin{array}{lll}\square \text { Chanthaburi } & \square \text { Chumphon } & \square \text { Krabi } \\ \square \text { Nakhonnayok } & \square \text { Nakhonphanom } & \square \text { Nakornsrithammarat } \\ \square \text { Narathiwat } & \square \text { Nonthaburi } & \square \text { Pattani } \\ \square \text { Phangnga } & \square \text { Phatthalung } & \square \text { Phuket } \\ \square \text { Prachinburi } & \square \text { Ranong } & \square \text { Rayong } \\ \square \text { Satun } & \square \text { Songkhla } & \square \text { Suratthani } \\ \square \text { Trang } & \square \text { Trat } & \square \text { Uttaradit } \\ \square \text { Yala } & \end{array}$

Figure 1. The technical efficiency score of Thai durian production in each province

\section{Conclusions}

This study has measured the TE of durian production from 2012 to 2016 and research areas consisted of 22 provinces in Thailand. For this reason, the DEA model was the main research method for this study. The TE score of Thai durian production revealed favorable results; however, the production still needs to be improved since the TE score is not close to 1.000. In addition, the empirical results indicated that Chanthaburi province had the most effective in Thai durian production from year 2012 to 2016 as compared with other durian producing provinces. This suggests that the Chanthaburi province is best suited for durian production in Thailand. On the other hand, Phuket province had the worst efficiency score for durian production when compared to other provinces in Thailand. The cause could due to overuse of input factors, resulting in low quantity of durian production. Therefore, it caused inefficiency as well as poor production rates. Moreover, this study can provide important information to farmers, planners and government agencies to define strategies that are useful and helpful to increase the efficiency in each province for Thai durian production. 


\section{References}

1. Banker, R. D., Charnes, A., \& Cooper, W. W. (1984). Some models for estimating technical and scale inefficiencies in data envelopment analysis. Management Science, 30(9), 1078-1092.

2. Charnes, A., Cooper, W. W., \& Rhodes, E. (1978). Measuring the efficiency of decision making units. European journal of Operational Research, 2(6), 429-444.

3. Coelli, T. J., Prasada Rao, D., O’Donnell, C. J., \& Battese, G. E. (2005). Data envelopment analysis. An Introduction to Efficiency and Productivity Analysis, 161-181.

4. Dhungana, B. R., Nuthall, P. L., \& Nartea, G. V. (2004). Measuring the economic inefficiency of Nepalese rice farms using data envelopment analysis. Australian Journal of Agricultural and Resource Economics, 48(2), 347-369.

5. Hadad, Y., Friedman, L., Sinuany-Stern, Z., \& Ben-Yair, A. (2008). Ranking method based on the difference between weighted output and input. Comput Model New Technol, 12(3), 55-65.

6. Krasachat, W. (2004). Technical efficiencies of rice farms in Thailand: a non-parametric approach. The Journal of American Academy of Business, Cambridge, 4(1), 64-69.

7. Krasachat, W. (2012). Organic production practices and technical inefficiency of durian farms in Thailand. Procedia Economics and Finance, 3, 445-450.

8. Krasachat, W. (2014). Technical efficiency of organic durian farms in Thailand. Paper presented at the 8th International Scientific Conference on Economic and Social Development and 4th Eastern European ESD Conference: Building Resilient Economy, Zagreb, Croatia.

9. Longpichai, O., Perret, S. R., \& Shivakoti, G. P. (2012). Role of livelihood capital in shaping the farming strategies and outcomes of smallholder rubber producers in southern Thailand. Outlook on Agriculture, 41(2), 117-124.

10. Mailena, L., Shamsudin, M. N., Radam, A., \& Latief, I. (2014). Rice farms efficiency and factors affecting the efficiency in MADA Malaysia. Journal of Applied Sciences, 14(18), 2177.

11. Meeusen, W., \& Van den Broeck, J. (1977). Technical efficiency and dimension of the firm: Some results on the use of frontier production functions. Empirical Economics, 2(2), 109-122.

12. Mohammadi, A., Rafiee, S., Jafari, A., Keyhani, A., Dalgaard, T., Knudsen, M. T., . . . Hermansen, J. E. (2015). Joint life cycle assessment and data envelopment analysis for the benchmarking of environmental impacts in rice paddy production. Journal of Cleaner Production, 106, 521-532.

13. Nassiri, S. M., \& Singh, S. (2009). Study on energy use efficiency for paddy crop using data envelopment analysis (DEA) technique. Applied Energy, 86(7), 1320-1325.

14. OAE. (2016). Agricultural statistics of Thailand in 2015. Ministry of Agriculture and Cooperative, Office of Agricultural Economics, Bangkok, Thailand.

15. Parichatnon, S., Maichum, K., \& Peng, K.-C. (2017). Evaluating technical efficiency of rice production by using a modified three-stage data envelopment analysis approach: A case study in Thailand. International Journal of Scientific \& Technology Research, 6(1), 152-159.

16. Rahman, S., \& Rahman, M. (2009). Impact of land fragmentation and resource ownership on productivity and efficiency: The case of rice producers in Bangladesh. Land Use Policy, 26(1), 95-103.

17. Rahman, S., Wiboonpongse, A., Sriboonchitta, S., \& Chaovanapoonphol, Y. (2009). Production Efficiency of Jasmine Rice Producers in Northern and North- eastern Thailand. Journal of Agricultural Economics, 60(2), 419-435.

18. Sexton, T. R. (1986). The methodology of data envelopment analysis. New Directions for Evaluation, 1986(32), 7-29.

19. Sherlund, S. M., Barrett, C. B., \& Adesina, A. A. (2002). Smallholder technical efficiency controlling for environmental production conditions. Journal of Development Economics, 69(1), $85-101$. 
20. Son, T. V. H., Coelli, T., \& Fleming, E. (1993). Analysis of the technical efficiency of state rubber farms in Vietnam. Agricultural Economics, 9(3), 183-201.

21. Tung, D. T. (2014). Regional differences in measuring the technical efficiency of rice production in Vietnam: A metafrontier approach. Journal of Agricultural Science, 6(10), 147.

22. Van Passel, S., Van Huylenbroeck, G., Lauwers, L., \& Mathijs, E. (2009). Sustainable value assessment of farms using frontier efficiency benchmarks. Journal of Environmental Management, 90(10), 3057-3069.

23. Wijnhoud, J., Konboon, Y., \& Lefroy, R. D. (2003). Nutrient budgets: sustainability assessment of rainfed lowland rice-based systems in northeast Thailand. Agriculture, Ecosystems \& Environment, 100(2), 119-127. 